\title{
Evaluation of the polysilicate-type flocculant on the water treatment process
}

\author{
D. Gologan \\ Quality and Treatment Water Department WTP, Romania
}

\begin{abstract}
Flocculants are chemicals that speed up the aggregation of destabilized particles by increasing the efficiency of their removal. Due to the impact that residual substances which are found in water treatment reagents has on consumers' health, replacing polyacrylamide flocculants has become a priority. In order to address this issue, a polysilicate type flocculant was evaluated in two steps. The first step was performed in laboratory conditions, on raw surface water, along with four types of coagulants: aluminium-sulfate, two different types of polyaluminum-chloride-hydroxide, and polyaluminum-chloride-hydroxydesulfate, which is a bi-component coagulant. The second step consisted of studies performed at an industrial level. During these studies, the polysilicate and the polyacrylamide type flocculants were compared, in combination with the polyaluminum-chloride-sulfate type coagulant. The purpose of these studies was to determine which one yielded better results, in terms of reducing turbidity and organic carbon deposits (TOC, DOC, BDOC) contained within raw surface water. The results obtained through these studies clearly showed that for potable water treatment, the polysilicate type flocculant was a superior replacement to the polyacrylamide type.

Keywords: flocculant, aluminum polysilicate, organic substances removal.
\end{abstract}

\section{Introduction}

During the conventional water treatment process, coagulation and flocculation are the key steps that determine the destabilization and accumulation of particles; particles which can then be removed by the sedimentation and filtration processes [1]. Decreasing the turbidity of the water, at the point it leaves the water tanks, leads to an increased efficiency in reducing suspended matter along 
with organic and microbial content. It also ensures a more efficient filtration and disinfection phase. Organic flocculants based on polyacrylamide are considered to be carcinogenic, therefore the maximum admissible monomer dose is $0.1 \mu \mathrm{g} / \mathrm{l}$ [2] compounds. Because of these effects, flocculants with a complex silicon structure along with bio-flocculants have appeared on the market. As an added benefit, recently published research has shown the positive role of silicon in the treatment of Alzheimer's disease [3]. The aluminium polysilicate type flocculant which is referred to within this paper is manufactured by Mosslein $\mathrm{GmBH}$ Germany. It can be used in the process of coagulation-flocculation, in conjunction with an aluminium-based coagulant-type mono-metal, such as aluminium sulfate, or a pre-hydrolyzed type such as polyaluminum-chloridehydroxide or polyaluminum-chloride-hydroxyde-sulfate.

\section{Experimental phase}

Testing of the polysilicate flocculant was performed in laboratory and industrial conditions, on raw surface water (from Paltinu Dam). Raw water has a medium hardness between 10.6 and 11.8 German degrees; its mineral content is due to calcium sulfate and calcium bicarbonate. The natural organic matter is derived from soil degradation processes and the processes of eutrophication.

Table 1: Raw water quality.

\begin{tabular}{|c|c|c|c|c|}
\hline Name & Unit & Mean & Minim & Maxim \\
\hline Turbidity & $\mathrm{NTU}$ & 24.7 & 3.5 & 4120 \\
\hline Temperature & ${ }^{\circ} \mathrm{C}$ & 9.87 & 1.7 & 20.5 \\
\hline $\mathrm{pH}$ & $\mathrm{unit}$ & 8.04 & 7.95 & 8.47 \\
\hline Nitrate & $\mathrm{mg} / 1$ & 2.33 & 0.88 & 5.28 \\
\hline Nitrit & $\mathrm{mg} / 1$ & 0.02 & 0.008 & 0.12 \\
\hline Amonium & $\mathrm{mg} / 1$ & 0.03 & 0.1 & 0.17 \\
\hline Oxidability & $\mathrm{mg} / 1 \mathrm{O}_{2}$ & 2.94 & 0.64 & 11.2 \\
\hline UV 254 & $\mathrm{~cm}{ }^{-1}$ & 0.043 & 0.018 & 0.078 \\
\hline TOC & $\mathrm{mg} / 1 \mathrm{C}$ & 4.2 & 3.5 & 5.5 \\
\hline DOC & $\mathrm{mg} / \mathrm{l} \mathrm{C}$ & 3.04 & 2.64 & 3.5 \\
\hline BDOC & $\mathrm{mg} / 1 \mathrm{C}$ & 1.02 & 0.89 & 1.3 \\
\hline Clostridium perfringens & $\mathrm{UFC} / 100 \mathrm{ml}$ & 45 & 12 & 78 \\
\hline E. coli & $\mathrm{UFC} / 100 \mathrm{ml}$ & 74 & 12 & 1294 \\
\hline
\end{tabular}


The methods of analysis used to determine the chemical and microbiological parameters are:

- $\quad$ Turbidity - ISO 7027;

- $\quad$ Residual aluminum - ISO 10566;

- $\quad$ E coli -ISO 9308-1;

- Clostridium Perfringens bacteria - m-CP agar method;

- $\mathrm{UV}_{254}$-Standard Methods, 19th. Ed, Method 5910;

- Total organic carbon (TOC) EN 13137;

- Dissolved organic carbon (DOC), 0,45 $\mu \mathrm{m}$ membrane filtration of samples and determination according to EN 13137;

- Biodegradable organic carbon (BDOC) - Method Joret - Levi, inoculated in each sample of biologically active sand [4].

\subsection{The laboratory tests}

The Jar test method was used for laboratory tests. It involves the following steps: rapidly mixing raw water at $150 \mathrm{rpm} / \mathrm{min}$ for 1 minute without adding the reactant, then adding the coagulant, continuing to $\operatorname{mix}$ at $150 \mathrm{rpm} / \mathrm{min}$ for 3 minutes, after that, adding the flocculant, slowly mixing at $40 \mathrm{rpm} / \mathrm{min}$ for 5 minutes, allowing 30 minutes of rest, and then collecting the supernatant. The flocculant was tested along with four types of coagulants, which are based on the aluminums displayed in Table 2.

Table 2: The types and characteristics of the coagulants used in the experiment.

\begin{tabular}{|c|c|c|c|c|}
\hline No & Name & $\begin{array}{l}\text { Trading } \\
\text { symbol }\end{array}$ & $\begin{array}{l}\text { Chemical } \\
\text { formula }\end{array}$ & $\begin{array}{c}\text { Active } \\
\text { substance } \\
\text { content }\end{array}$ \\
\hline 1 & $\begin{array}{l}\text { Aluminum } \\
\text { sulfate }\end{array}$ & SAL & $\mathrm{Al}_{2}(\mathrm{SO} 4)_{3}$ & $\begin{array}{c}17 \% \\
\mathrm{Al}_{2} \mathrm{O}_{3}\end{array}$ \\
\hline 2 & $\begin{array}{c}\text { Polyaluminum } \\
\text { chloride } \\
\text { hydroxide } \\
\end{array}$ & PAC 1 & {$\left[\mathrm{Al}(\mathrm{OH})_{\mathrm{a}} \mathrm{Cl}_{\mathrm{b}}\right]$} & $\begin{array}{c}10 \% \\
\mathrm{Al}_{2} \mathrm{O}_{3} \\
12 \% \mathrm{Cl} \\
\end{array}$ \\
\hline 3 & $\begin{array}{l}\text { Polyaluminum } \\
\text { chloride } \\
\text { hydroxyde sulfate }\end{array}$ & PAC 2 & {$\left[\mathrm{Al}(\mathrm{OH})_{\mathrm{a}} \mathrm{Cl}_{\mathrm{b}} \mathrm{SO}_{4 \mathrm{c}}\right]$} & $\begin{array}{c}14 \% \\
\mathrm{Al}_{2} \mathrm{O}_{3} \\
9 \% \mathrm{Cl} \\
2 \% \mathrm{SO}_{4}\end{array}$ \\
\hline 4 & $\begin{array}{l}\text { Polyaluminum } \\
\text { chloride } \\
\text { hydroxide }\end{array}$ & PAC 3 & {$\left[\mathrm{Al}(\mathrm{OH})_{\mathrm{a}} \mathrm{Cl}_{\mathrm{b}}\right]$} & $\begin{array}{l}21.5 \% \\
\mathrm{Al}_{2} \mathrm{O}_{3} \\
9 \% \mathrm{Cl}\end{array}$ \\
\hline
\end{tabular}

The polysilicate flocculant type used in this experiment content:

$\sim 243 \mathrm{mg} / \mathrm{l} \mathrm{Al}$ and $915 \mathrm{mg} / 1 \mathrm{SiO}_{2}$.

The results of the laboratory experiments demonstrated the capability of the polysilicate flocculant to decrease the degree of raw water turbidity by $10-40 \%$, this depending on the type of coagulant used. Furthermore, lower residual 


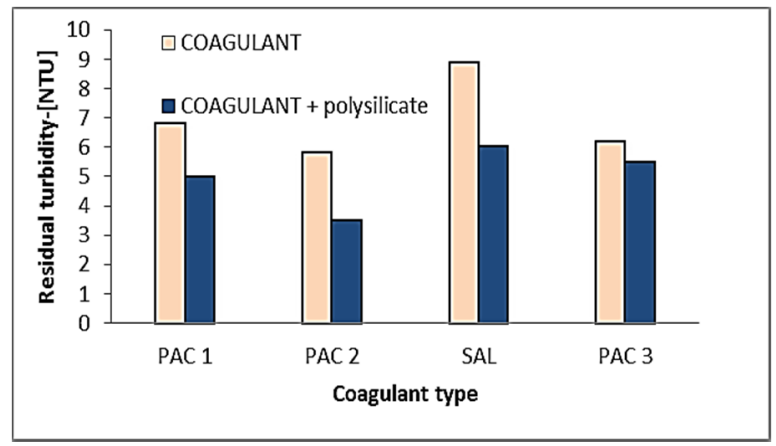

Figure 1: Residual turbidity with and without the polysilicate flocculant.

turbidity values were also obtained after using the polysilicate flocculant, in comparison with the values which were obtained when only the coagulant was used.

The polysilicate flocculant was tested in order to evaluate the degree of residual substances that remained in water (aluminium and silicate). With regards to residual aluminium, Figure 2 displays the comparison between using only a coagulant, and using a coagulant with a polysilicate flocculant. The polysilicate flocculant was noted to reduce residual aluminium content by $14 \%$ to $21 \%$, due to its larger size and its removal ability.

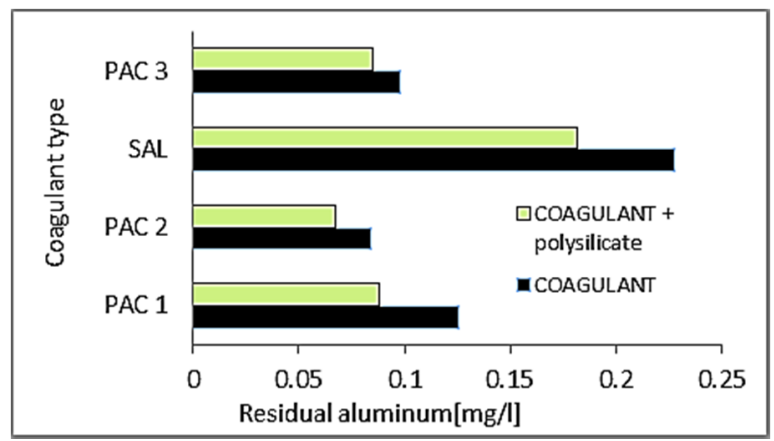

Figure 2: Residual aluminum content with and without the polysilicate flocculant.

With regards to the residual silicate content, no further growth was noticed versus what was already present in the raw water which was tested. Actually, based on the type of coagulant used, one can notice a decrease in the silicate content, which was due to the mechanism that forms chains between the flocculated particles and their subsequent sedimentation.

The polysilicate flocculantre removes a higher degree of bacteria from raw water. As a result, bacteria such as Coliform, E. coli and Clostridium Perfringens are efficiently reduced (i.e. Figures 3 and 4). 


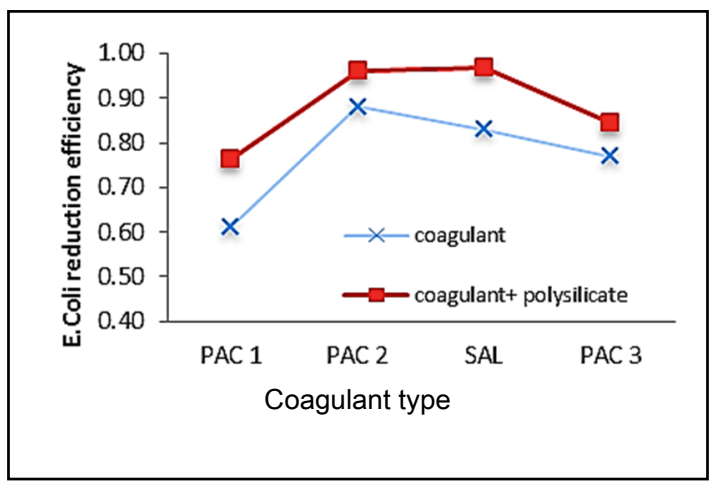

Figure 3: Reduction efficiency on E. coli bacteria with and without the polysilicate flocculant.

Reduction efficiency of the clostridium Perfringens and E. coli bacteria was calculated using this formula:

$$
\operatorname{EFR}(\text { bacteria })_{i}=\frac{(\text { bacterianw })-(\text { bacteria })}{(\text { bacteriaRw })}
$$

where:

bacteria - clostridium Perfringens or E. coli [nr/100ml];

(bacteria $\mathrm{RW}_{\mathrm{R}}$ ) - concentration of clostridium Perfringens or E. coli in raw water; (bacteria $a_{i}$ - concentration of clostridium Perfringens or E. coli from the supernatant of the sample treated with the coagulant $i ; i-$ the coagulant, $i=1 \ldots 4$.

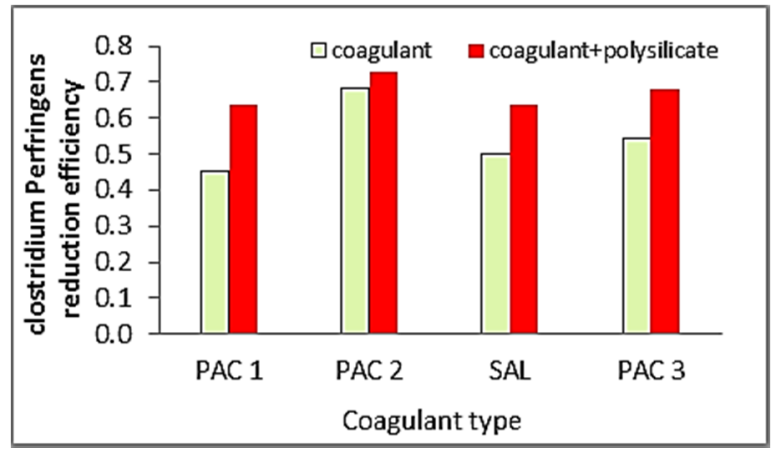

Figure 4: Reduction efficiency on clostridium Perfringens bacteria with and without of polysilicate flocculant.

The E coli reduction efficiency was increased by $7-15 \%$ and clostridium Perfringens reduction efficiency was increased by $6-19 \%$. 


\subsection{The industrial level experiments}

The evaluation of the polysilicate type flocculant and the comparison made to the polyacrylamide type was performed at an industrial line containing two water settling tank. In one of the water settling tank there was used the anionic polyacrylamide type flocculant, and in the other, the polysilicate type flocculant was used. In both these cases, the polyaluminum-chloride-hydroxyde-sulfate PAC 2 coagulant was used. The experiment was performed over a 20 day period.

The polysilicate type flocculant in combination with the polyaluminumchloride-hydroxyde-sulfate coagulant achieved superior results in reducing turbidity versus the ones obtained with the polyacrylamide type flocculant .The average turbidity of the water treated with the polysilicate flocculant was $64 \%$ lower than that treated with the polyacrylamide flocculant (Figure 5). The polysilicate's performance was not affected after reducing its dose by $20 \%$, in comparison with the one measured when using the polyacrylamide. The medium turbidity of the water treated with the polysilicate flocculant, at a dose of $0.08 \mathrm{mg} / 1$, was $36 \%$ lower than that treated with the polyacrylamide, at a dose of $0.1 \mathrm{mg} / 1$.

The effect of both flocculants in conjunction with the coagulant in reducing the organic carbon is shown in Figure 6.

Taking into consideration technological efficiency, and the results obtained during the research, it has been concluded that in flow treatment, the silicon based flocculant in combination with a pre-hydrolyzed coagulant, is a good replacement for polyacrylamide, As a result, better potable water was obtained and the level of the water's bio-stability was increased (BDOC reducing efficiency).

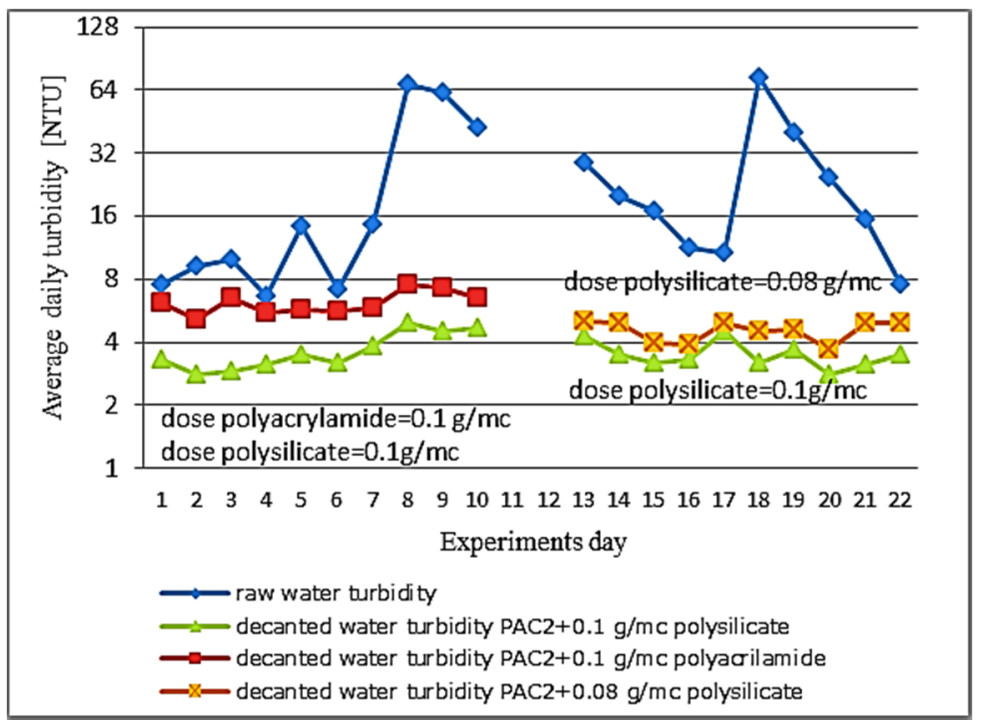

Figure 5: Daily average turbidity values - comparative testing of flocculants at an industrial level. 


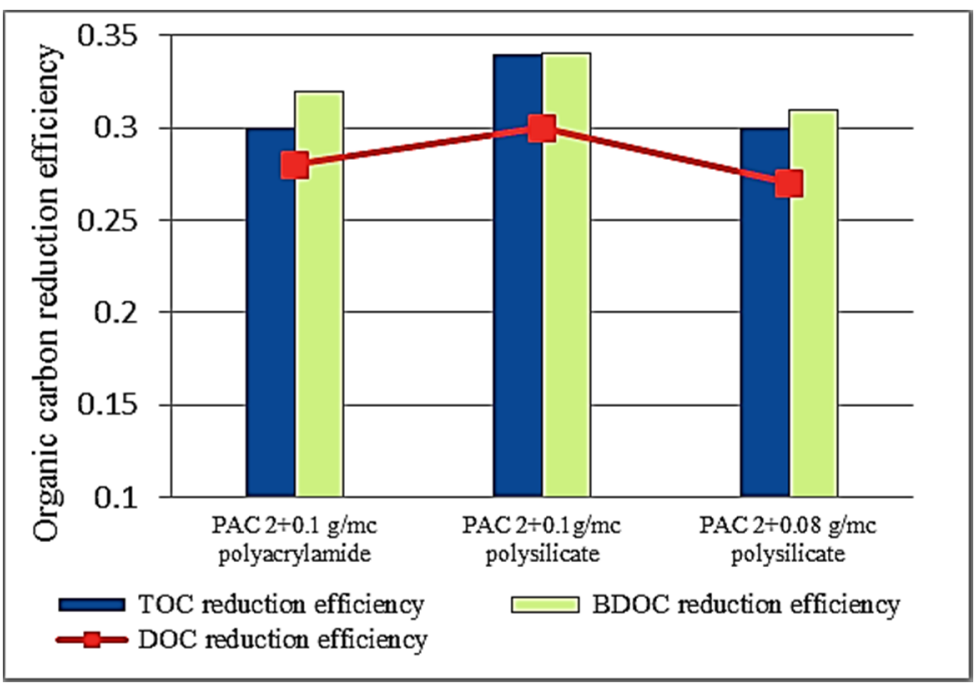

Figure 6: Efficiency of $\mathrm{TOC}, \mathrm{DOC}$ and $\mathrm{BDOC}$ reduction for polysilicate compared to polyacrylamide at an industrial level.

\subsection{Routine use of polysilicate floculant in water treatment}

After analysing consumption rates during a period of 120 days, while routinely using the polysilicate flocculant, a $13 \%$ decrease in coagulant consumption was measured. Furthermore, when the raw water turbidity was under 10 NTU, the coagulant dose could be reduced by $20-25 \%$ and the desired results were still attained (Figure 7).

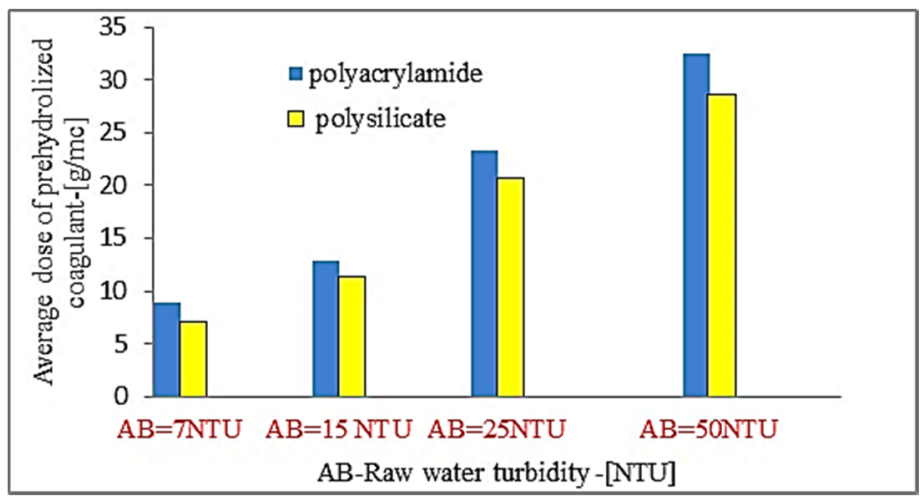

Figure 7: The average dose of coagulant when using polysilicate vs. polyacrylamide, at an industrial level.

The polysilicate flocculant significantly increases the bacteriological content removal efficiency in raw water. Bacteria such as heterotrophic bacteria, 
coliform bacteria, E. Coli, clostridium Perfringens, are still efficiently removed even after reducing the disinfecting dose by $33 \%$ (Figure 8 ).

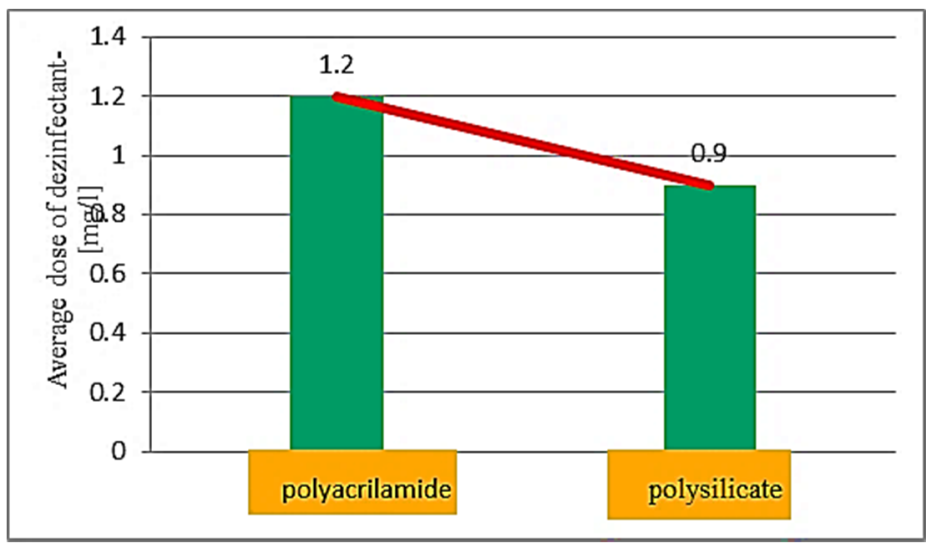

Figure 8: Disinfectant dose of polysilicate vs. polyacrylamide, at an industrial level.

\section{Conclusion}

The polysilicate flocculant increases the efficiency of aluminium based coagulants, so the turbidity of decanted water is decreased with $10-40 \%$ depending on the type of coagulant. This flocculant type decreases the residual aluminum content in water by $14-21 \%$ and increases the efficiency of organic substances and pathogenic bacteria removal (coliform, E. Coli, etc.) by 5-19\% depending of the type of bacteria.

The polysilicate flocculant leads to a decrease of approximately $10 \%$ in the cost of the coagulation-flocculation process. This is due to the fact that there can be used reduced doses of disinfectant and coagulant in conjunction with this flocculant, without affecting their efficiency. Therefore, the material costs for the treatment plant will also be reduced.

The operating costs for polysilicate are 6 times lower than for polyacrylamide. More than that, the dosing system for polysilicate requires only a simple and inexpensive metering pump. However, the polyacrylamide system is more complex and requires a metering pump that can properly age the solution and dry dose at appropriate times.

Due to the increased focus on the quality of potable water and the new requirements which are becoming more and more restrictive with regards to the concentration of secondary reactants (coagulation-flocculation items), better alternatives must be found. These alternatives must reduce the concentration of residual aluminium and acrylamide, and increase the efficiency of biobacteriological and organic component reduction in raw water which is meant to be used as drinking water (without harming consumer's health). 


\section{References}

[1] Crittenden, J. C., Trussell, R. - “MWH's Water Treatment: Principles and Design", Third Edition, cap 6-9, 2012.

[2] Word Health Organization - "Guidelines for Drinking-water Quality", fourth edition, 2011.

[3] Exley, C. - "A Silicon - Rich Mineral Water Therapy for Alzheimer's Disease" - Journal of Alzheimer's Disease Vol. 33, No. 2, 2012.

[4] Joret, J, Levi Y, Volk C. - "Biodegradable dissolved organic carbon (BDOC) content of drinking water and potential regrowth of bacteria", Water Sci. Technol. 2, pp. 95-101, 1991. 